\title{
Contribuição para um Programa Municipalista Minimo
}

\section{YVES DE OLIVEIRA}

\author{
(Representante do Brasil junto à Comissão Pane- \\ mericana de Cooperação Intermunicipal - Cor- \\ selheiro da Associação Brasileira de Municípios \\ - Presidente da Associação dos Municípios da \\ Bahia e Diretor da Revista de Direito Muni- \\ cipal)
}

\begin{abstract}
A
nossa experiência no movimento municipalista nos levou a sistematizar idéias e resoluções dos Congressos e reuniões amıricanos, nacionais e regionais relativos ao desenvolvimento do Direito, da Ciência e Administração Municipais, elaborando uma modesta contribuição para um Programa Municipalista Mínimo.

Visamos com isto dar uma maior unidade espiritual a êsse magnífico movimento de revitalização dos municípios. Não é um trabalho definitivo. Pelo contrário, desejamos críticas, sugestões. tendo em mira um aperfeiçoamento mais detalhado e profundo das idéias formuladas em um tom orgânico. Bem sabemos e avaliamos das dificuldades encontradas, contudo a evolução da doutrina municipalista está numa fase que exige preocupação sistematizadora. Os arautos dessa doutrina não devem recuar ante as possíveis dificuldades de dar objeto delimitado ao seu campo de ação.

O nosso País vive em crise permanente de evolução, ao lado dơ desenvolvimento industrial e técnico do mundo moderno.

As populações de nosso interior não podem continuar a viver em condições antagônicas de civilização moderna de certos centros metropolitanos. Urge uma política capaz de sanar os males dêsse desajustamento econômico, social e ético.

Assim, elaboramos êste Programa Municipalista Mínimo, que representa e encarna uma contribuição de quem tem dado tudo pela doutrina de valor1zação da vida local no mundo hodierno, em benefício do Homem e do perfeito equilíbrio dos grupos sociais e comunidades.
\end{abstract}

\section{PROGRAMA MUNICIPALISTA}

\section{Aspecto filosófico}

Considera:

$1^{\circ}$ ) A luta dos Municípios por uma filosofia alicerçada no equilíbrio econômico, político e ético dos grupos sociais, e das comunidades humanas. 
2. ${ }^{\circ}$ ) A prática da teoria da Intermunicipalidade universal, defendida magnificamente pelo eminente Rui de Lugo Viña e em virtude da qual se torna extensivo aos Municípios o direitơ de ccoperação internacional, como já vem acontecendo com a Comissão Panamericana de Cooperação Internamunicipal, com sede em Cuba.

Visa:

\section{Aspecto politico e constitucional}

$1^{\circ}{ }^{\circ}$ A implantação no País de uma República Municipalista, baseada 1a descentralização pclítica e administrativa, em três esferas do govêrno: a União, os Estados-Membros e os Municípios, cada qual exercendo poderes constituintes, a moldes do que ocorre com o Rio Grande do Sul.

$\left.2 .^{\circ}\right)$ A extensão, aos vereadores, da prerrogativa da imunidade que é cutorgada aos deputados e senadores.

Objetiva:

\section{Aspecto administrativo} tral.

1. $\left.{ }^{\circ}\right)$ Transferência imediata da Capital do Brasil para o Planalto Cen-

2..$^{\circ}$ Solução dos problemas de base do país, destacadamente os de transportes, energia elétrica e educação.

$3^{\circ}$ ) Descentralização administrativa dos serviços de assistência e prcvidência, de molde a facilitar o contato entre a instituição e o segurado, garantindo maior rapidez na concessão dos benefícios.

4. ${ }^{\circ}$ ) Elaboração de Códigos Municipais em cada Comuna, visando dar unidade às Leis locais. condensando quanto possível em um só corpo legislativo a matéria municipal.

5. ${ }^{\circ}$ ) Instituição do sistema de recrutamento para o serviço públicơ pelo critério do mérito, não bastando porém, tão só selecionar, e sim também orientar e proceder a uma revisão periódica, devendo-se ressaltar a contribuição da psicotécnica para êste importante e fundamental objetivo.

\section{Aspecto econômico}

Tem por objetivo:

$1^{\circ}{ }^{\circ}$ Valorização dos planejamentos urbanos, rurais e regionais, dando-se ênfase administrativa aos problemas intermunicipais de base: transportes, energia elétrica e educação.

2. ${ }^{\circ}$ ) Cobrança de uma taxa de planejamento, nos Municípios, para elaboração dos planos e projetos do govêrno local.

$3 .^{\circ}$ ) Instalação sob a forma cooperativa, de bancos regionais, destinados a servir de base a um futuro instituto de crédito municipal.

4. ${ }^{\circ}$ ) Cocperação entre os Municípios, para criação de sociedades de fins econômicos, quando a execução dos acordos intermunicipais o tornar necessário, podendo participar do empreendimento pessoas físicas ou jurídicas.

5. ) Apoio à reforma agrária que deverá realizar-se através da cooperação e do esfôrço conjugados dos três níveis de govêrno. 
$6^{\circ}$ ) Incentivo à criação de Bancos dos Municípios, com o fim de reter no interior as fortunas ali formadas.

7. ${ }^{\circ}$ ) Participação efetiva dos Estados e Municípios nos lucros resultantes da exploração, industrialização e prospecção petrolíferas, no respectivo território; o que é reconhesido de absoluta conveniência.

Pretende:

\section{Aspecto financeiro}

$1^{\circ}$ ) A reforma da Constituição brasileira para que se objetivem novas discriminações de rendas no País, visando o melhoramento das condições financeiras dos municípios, terminando-se de uma vez por tôdas, com o sistema de auxílios permanentes nos orçamentos aos mesmos por parte da União e dos Estados-Membros, a não ser em caráter excepcional .

$2^{\circ}$ ) A instituição do Código Tributário Nacional, como medida indispensável à consolidação, pelas três esferas governamentais, das reivindicações municipalistas através de nítida delimitação dos campos de competência e de obediência às diretrizes básicas de uma política tributária definida em plano nacional.

3. ${ }^{\circ}$ ) A percepção de quarenta por cento pelos Municípios, do total das rendas públicas arrecadadas no País, dentro em prazo razoável e de modo progressivo. mediante outorga de novos tributos.

Resolve:

\section{Aspecto educacional}

$1^{\circ}$ ) Considerar a educação um problema de base capaz de ajudar a solucionar a crise brasileira, acabando-se com o analfabetismo.

$\left.2 .^{\circ}\right)$ Elaborar-se um plano geral do ensino rural, com a colaboração dos Municípios e de instituições interessadas no fomento agrícola.

3. ${ }^{\circ}$ ) Intensificar o ensino profissional no interior brasileiro.

4. ${ }^{\circ}$ ) Propagar o ensino técnico, instalando-se os respectivos cursos ao lado de cada Ginásio do Interior, segundo o plano dos Centros Regionais de Educação.

Insiste:

\section{Aspecto científico e didático}

$1^{\circ} .^{\circ}$ Considerar-se o municipalismo uma ciência municipal autônomd: com metodologia própria.

2. ${ }^{\circ}$ ) Incorporação aos planos de estudos por parte das Faculdades de Direito e Ciências Econômicas do Continente da disciplina denominada: "Direito, Ciência e Administração Municipal".

3. ) Criação de institutos de altos estudos para peritos em administração municipal e urbanistas planificadores.

4. ${ }^{\circ}$ ) Instituição sistemática, em cada núcleo urbano, de um plano de urbanismo.

5..$^{\circ}$ O ensino nas escolas primárias de noções sôbre a doutrina municipalista, valorizando-se os problemas locais. 


\section{Adota:}

\section{Aspecto sanitário}

$1^{\circ}$ ) A resolução dos problemas de saúde pública, paralelamente com os de assistência social, não adiantando estudar um sem pensar nơ outro.

2..$^{\circ}$ Elaboração de um plano geral referente aos serviços de suprimento de água e às rêdes coletoras em tôdas as localidades brasileiras.

3. ${ }^{\circ}$ ) Assistência hospitalar em todos os Municípios devendo o Serviço de saúde do interior seguir uma orientação de medicina preventiva, de higiene, de profilaxia e de assistência pròpriamente dita.

Tenciona:

\section{Aspecto estatístico}

Manter os Convênios Nacionais de Estatística Municipal, em face dos seus meritórios e relevantes serviços, como centros coordenadores e executores de trabalhos de interêsse local.

Tem em mira:

\section{Aspecto juridico}

$1^{\circ}$ ) Maior unidade e prestígio para o Poder Judiciário. Justiça.

2..$^{\circ}$ Representação dos Estados-Membros no Supremo Tribunal de

3. ${ }^{\circ}$ Estímulo aos magistrados do País incentivando-os ao estudo e aprimoramento das qualidades de cultura e as inerentes à técnica de julgar.

4..$^{\circ}$ Igualar ao número de Ministros do Supremo Tribunal de Justiça ao dos Estados-Membros, escolhidos, por exclusivo merecimento e lista tríplice, pelo próprio Supremo Tribunal de Justiça e de nomeação pelo Presidente da República.

5. $^{\circ}$ ) Instituição de Câmaras especializadas nos Tribunais.

\section{Recomenda:}

\section{Aspecto internacional}

A manutenção de vínculơs de cooperação municipal com as entidades dos países americanos que se dedicam ao estudo e defesa dos problemas locais, valorizando-se o princípio da Intermunicipalidade Universal de Rui de Lugo Vinha, ao lado da execução dos postulados contidos nas Castas de Rccomendação dos Congressos Interamericanos e Internacionais de Municípios.

\section{Aspecto moral e ético}

Que o povo brasileiro repudie e despreze a demagogia "política", o votc inconsciente, a ausência de espírito público, a desonestidade pessoal e a falta de caráter daqueles que têm parcela de direção na causa pública, visando-se com isso o bem comum, a segurança e a justiça em nome de uma melhor pclítica democrática e de mais aprimorada educação cívica. 